\title{
Review
}

\section{Every twelve seconds: Industrialized slaughter and the politics of sight}

\author{
Timothy Pachirat \\ Yale University Press, New Haven, CT, 2011, xii+302pp., £60.00/\$30.00, \\ ISBN: 978-0300152678
}

Contemporary Political Theory (2014) 13, e1-e3. doi:10.1057/cpt.2013.9

Every Twelve Seconds is an account of industrialized slaughter written from the perspective of the workers who carry it out. The book draws on extensive ethnographic fieldwork and interviews, conducted over a period of two and a half years in a slaughterhouse in Omaha, Nebraska. During this period, Pachirat spent over 5 months as an employee, working through various sections of the slaughterhouse from the chutes, where live cattle are driven into the knocking box to be shot, to the cooler, where carcasses and body parts are chilled, before finally taking up a position as a quality control official.

Pachirat aims to describe, from these three vantage points, how the gruesome work of killing is organized and how it is rendered tolerable to the workers who engage in it. One of the main contributions of the book, and one of the reasons why it may be of interest to political theorists, is that it shows in detail how organizational processes can work around our moral sentiments and how they can contribute to fragmenting our moral perception.

The book is primarily an exercise in participant observation. Pachirat attempts to stay as close as possible to his subject matter, and he largely refrains - apart from the introduction and conclusion - from making broad theoretical claims. He sets himself a task that is deceptively simple: to provide a detailed and unflinching description of killing work. His book is an invitation to see - to keep our eyes open in situations where most of us would prefer to close them. The scenes described are of a rare violence - they are at once grotesque, revolting and horrifying. And yet, this violence is never gratuitous or sensationalistic. All the while, the prose remains precise, and as free from value judgments as possible. Pachirat, to his credit, does not presume that the reader will be repelled and infuriated in principle (the language of animal rights is entirely absent) - he simply enjoins us to look at industrialized slaughter for what it is.

In addition to describing how killing work is organized, the book also shows what it is like for workers to perform it. Pachirat brings to life the smells they have to contend with and the sounds they are exposed to; he relates vividly the tactile

(c) 2014 Macmillan Publishers Ltd. 1470-8914 Contemporary Political Theory Vol. 13, 2, e1-e3 
experience of handling live cattle or raw meat, and gives us a feel for the frenzied and deadening pace of line work. His account conveys something of the phenomenology of everyday work. It also adds much texture to the routine of everyday life: we learn not just about the tedium of rules and procedures, but also about the informal relationships that exist among workers, and the everyday pranks and jokes that provide respite from boredom.

Pachirat's guiding concern, throughout the book, is to understand how workers can come to live with the violence that they encounter on a day-to-day basis. This is a question that most of us do not have to answer, because the slaughterhouse serves to conceal such violence from the rest of society. But what about those working within the slaughterhouse? Interestingly, it turns out that concealment is also at work there. Pachirat describes how the production line is divided into several areas that are adjacent to each other, but that are nevertheless physically and visually segregated. Out of the 800 workers who work at the slaughterhouse, only eight or so ever interact with live animals. The rest come in contact with material that has already been homogenized and stripped of individuating features. The majority of workers do not deal with cattle, but with beef. If we add to such de-individuation the frantic pace of the line (the title, Every Twelve Seconds, marks the cadence at which cattle are killed and processed), the minute parcellization of labor and its ongoing monotony, we can begin to understand why the experience of line workers is fragmented and why their attention is diverted from the ghastly sight of the carcasses hanging over the heads.

To be sure, the features that I have just mentioned (de-individuation, parcellization, rapid cadence and routinization) are well-known characteristics of the bureaucratic organization of labor, and their effect on the moral personalities of line workers has already been explored, though rarely with as much care and subtlety. What is distinctive about Pachirat's account, however, is that he also looks at two other categories of workers who have a more direct experience of the activity of killing: chute workers and quality control officials. Workers in the chutes are in close contact with individual animals, whereas quality control officials are free to roam around the slaughterhouse and can gain a holistic view of the entire process. How can these workers, who have a much clearer view of what is taking place, still bear the sight?

The answer, it turns out, is disturbingly mundane. Pachirat shows that these workers are, in large part, absorbed in small ongoing conflicts that divert their attention from the violence of everyday work. Surprisingly, most of these conflicts revolve around quality control. In the chutes, Pachirat's attention and that of his co-workers was entirely monopolized by the imperative to keep the line in motion an imperative that may involve ruthlessly applying electric shocks to animals to get them to move faster - without attracting the attention of the plant's governmental inspectors (from the United States Department of Agriculture), who would not have tolerated such behavior. How to keep the line moving without getting caught? This, and not the activity of killing, is what chute workers were preoccupied with. Something similar occurred in quality control, where Pachirat found himself locked, 
once again, in a struggle against USDA inspectors whose criticism he had to preempt. His mind was no longer on killing work, or on the possible contamination of the meat: he had become solely preoccupied with not being written up for safety violations. As Pachirat puts it, 'experimental compartmentalization is produced even ... under conditions of total visibility' (p. 232). Organizations do not have to hide the dirty work: it is enough for workers to be distracted by a more pressing concern.

Pachirat concludes the book by engaging with the 'politics of sight' - the assumption, common in political and critical discourse, that simply making the appalling nature of our practices and institutions visible is enough to transform them (p. 247). Pachirat does not seek to discredit this impulse entirely, but he sounds two notes of caution. First, as his ethnographic work shows, visibility can be compatible with concealment. Removing barriers to sight does not necessarily yield the benefits that one might expect.

Pachirat's second observation is more troubling. The politics of sight relies for its transformative potential on our moral sentiments: it is because we feel appalled and shocked by what we see, that we may be motivated to change our institutions and practices. But Pachirat argues that these very sentiments - of pity, compassion or indignation - are not as timelessly universal as Rousseau would have us believe. They are, as Elias (2000) had argued long ago, also the result of social institutions, of a 'civilizing process' that hides and segregates what is distasteful. It is the segregation of violence from everyday life that allows for the expansion of the sentiments of pity or compassion (p. 249).

Pachirat leaves us with the troubling thought that the moral sentiments on which we rely to criticize social institutions and practices may be in large part tributary to the existence of those very institutions and practices. 'The politics of sight', he writes, 'feeds off the very mechanisms of distance and concealment it seeks to overcome; sight and sequestration exist symbiotically' (p. 252). If it is to be effective, then, the politics of sight must be aware of its limits and cautious of the ways in which concealment and distance often provide the very conditions of its effectiveness (p. 255).

\section{Reference}

Elias, N. (2000) The Civilizing Process. Translated by E. Jephcott. Malden, MA: Blackwell.

Bernardo Zacka

Harvard University, Cambridge, MA 02138, USA 